\title{
Aclaración a una reseña del Diccionario de la Literatura Latinoamericana-Chile
}

En el número 48 de la Revista Iberoamericana (Julio-diciembre, 1959) hay una reseña de este Diccionario, firmada por el señor Homero Castillo. Como esta reseña presenta serios reparos a la obra, reparos con los cuales estoy a menudo de acuerdo, me creo obligado a hacer una aclaración. Dice el señor Castillo: "La ejecución de estos estudios fue realizada por Raúl Silva Castro, Arturo Torres-Rioseco, Luis Merino Reyes y Armando Correia Pacheco" (pág. 370) y agrega: "Además, para este Diccionario se ha podido contar con asesores tan competentes como TorresRioseco y Silva Castro" (pág. 37I), y por fin: "Hay una marcada diferencia entre las colaboraciones de Silva Castro y Torres-Rioseco y las de Merino Reyes y Correia Pacheco" (pág. 372).

La primera cita del señor Castillo indica que yo he sido el "ejecutor" de varios estudios contenidos en el Diccionario; la segunda, que yo he servido de asesor de la obra; y la tercera que mis colaboraciones son di. ferentes a las de Merino Reyes y Correia Pacheco.

Pues bien: el único estudio mío es el que versa sobre Gabriela Mistral. Este trabajo fue solicitado por el Sr. Correia Pacheco y pagado por la Unión Panamericana; yo no he sido en ningún momento asesor de esta obra; asesor es el que aconseja y en este caso yo no he aconsejado a nadie; es posible que "mi colaboración" sea diferente de la de los otros colaboradores, por su brevedad.

Esta aclaración tiene también otro propósito. En algún periódico de Chile un señor Iglesias me critica por haber escrito sobre literatura chilena estando ausente de Chile, me imagino que este señor habrá pen. 
sado que yo era uno de los asesores y que como él no aparece en el Diccionario la culpa era mía.

Tan ajeno he sido yo a la confección del Diccionario que hasta hoy no sé a quién agradecer la ficha a mí dedicada.

ARturo. Torres-Ríoseco

University of California, Berkeley, California. 